\title{
Growth, yield and nutritional content of finger millet (Eleusine coracana L.) as influenced by pranic energy application
}

\section{R. Poornima}

World Pranic Healing Foundation, India - Research Centre, Mysuru-570009 (Karnataka), India

\section{K. Nagendra Prasad}

World Pranic Healing Foundation, India - Research Centre, Mysuru-570009 (Karnataka), India

Srikanth N. Jois ${ }^{*}$

World Pranic Healing Foundation, India - Research Centre, Mysuru-570009 (Karnataka), India

${ }^{*}$ Corresponding author. Email: research@pranichealing.co.in

\section{How to Cite}

Poornima, R. et al. (2021). Growth, yield and nutritional content of finger millet (Eleusine coracana L.) as influenced by pranic energy application. Journal of Applied and Natural Science, 13(1): 42 - 50. https://doi.org/10.31018/jans.v13i1.2463

\begin{abstract}
Pranic agriculture (PA) is an ancient farming method where pranic energy improves crop production. Finger millet or Ragi (Eleusine coracana. L) is a major staple millet consumed in India, particularly Karnataka and is a rich source of protein and nutrients. A field study in half-acre was carried out with pranic energy treatment to seed, land and crop and along with control (without energy treatment). The traits of finger millet like plant height $(26 \%)$, number of productive tillers $(35 \%)$, no of panicle $(54 \%)$, number of fingers $(13 \%)$ and grain yield $(44 \%)$ were statistically $(p<.05)$ higher over control. Protein content in finger millet straw $(4.38 \%)$ and grain $(6.13 \%)$ was higher in pranic treatment than control (3.5 and $4.75 \%)$. Nitrogen and zinc content in millet grain was higher in pranic treatment $(980$ and $1.96 \mathrm{mg} / 100 \mathrm{~g})$ than control $(760$ and $1.63 \mathrm{mg} / 100 \mathrm{~g})$. The increase in protein, nitrogen and zinc content of the millet grain and straw will help to improve the quality of produce for consumption by cattle and humans. Increase in straw and grain yield will help to improve the economy of the farmer. Further studies are needed to know the actual mechanisms involved in the growth and yield improvement of finger millet. And, also in-depth studies are necessary to address the reasons behind the variation in nutrients accumulation in straw and grain.
\end{abstract}

Keywords: Ancient farming techniques, Energy farming inventions, Prana, Sustainable agriculture practices

\section{INTRODUCTION}

Pranic energy is an ancient knowledge which uses prana or life energy to heal the body. Growing of plants/ crops by application of pranic energy is called pranic agriculture (PA). Every entity, including plants and trees are surrounded by an energy field called bioplasmic body or 'Aura' (Sui, 2009). Scientists with the help of Kirlian's photography have rediscovered the bioplasmic body (Kirlian, 1949). This energy body keeps animals and plants healthy and alive. Prana treatment on agriculture crops is supplementary and complementary in nature. Pranic energy often referred as Chi or Ki or Prana are subtle and omnipresent and can be applied on crop plants by a trained pranic healer. Pranic energy cannot be measured because they are weak when compared to measurable energy forms like heat, sound and electricity. How the energy enters the plant system and brings about changes in the cellular and tissue is not yet understood. The previous report on use of pranic energy to enhance growth and yield in cucumber (Jois et al., 2017), drumstick (Prasad and Jois, 2019), papaya (Prasad and Jois, 2020) and ridge gourd (Poornima et al., 2020) have been reported. Pranic treated tomato and brinjal fruits showed an increase in storage capacity and qualities (Jois et al., 2016 and 2019). In the present global agriculture scenario, pranic agriculture (PA) could be a promising and supportive system to the sustainable and eco-friendly farming system.

Finger millet (Eleusine coracana L.), locally called as Ragi, is a minor millet and native of Ethiopia and is 
grown in many regions of India and Africa. Ragi is a third most important millet crop and staple food of India, which supplies calories and protein to the major portion of the population (Kennedy et al., 2006, Upadhyaya et al., 2006). In India, Karnataka produces a maximum quantity of finger millet accounting to $58 \%$ of its global production, yet only a few Indians are aware of its health benefits and nutritional value. The production area of finger millet in India stands sixth after wheat, rice, maize, sorghum and bajra (Chandra et al., 2016). Ragi seeds are a rich source of calcium, iron, dietary fiber, essential amino acids and antioxidants. It is also useful in managing various physiological disorders like hypertension, hypercholesterolemia, prevention of oxidation of low-density lipoproteins (LDLs), diabetes mellitus and also improves gastrointestinal health (Scalbert et al., 2005). Presence of five-layered testa in ragi makes it unique compared to other cereals, and it could be the reason for higher dietary fiber of ragi (Chandra et al., 2016).

Ragi is an underutilized crop grown in the local production system and an important part of the local diet, culture and economy. It could be a potential economically viable crop under water-scarce and adverse climatic conditions because of its hardiness and resistance to pest and diseases (Chandra et al., 2016). Ragi straw is a nutritious animal fodder and a good supplement for a dairy cow to get higher milk yield (Chandrasekharaiah et al., 2004). In view of the above multipurpose usage of ragi, E. coracana as both animal feed and human food, there is a need to improve the production and productivity of ragi to make it as an economic crop. Hence, pranic energy treatment was taken up in this study to improve the yield and quality of ragi crop.

\section{MATERIALS AND METHODS}

PA experiment was conducted during Kharif 2019, season (July to October) under field condition at farmer's field in Hesaraghatta, Bengaluru. The experiment was conducted in one acre of agriculture land. Seeds of ragi (var. MR-1) procured from the local market, were used for this study. The seeds were divided into pranic (Energy treatment) and control (without energy treatment). The agriculture land was divided into pranic and control plots measuring half-acre each and the distance between the two plots was six feet. Before sowing, seeds and the land of the pranic group received pranic energy in the form of prana (Sui, 2015). Treatment was given to seeds and land simultaneously for 6 times at an interval of 3 days and each treatment lasted for about 15 minutes. Treatment involved techniques to improve the quality and quantity of prana. The healer first prays for the almighty GOD during the healing process to receive his blessings. The healer then sensitizes his hands and scans the seeds/ soil. Any contaminated energies are perceived as heavy energies, which are felt in his hands. These contaminated energies are then removed by flicking these used up/ dirty energies into a saltwater bowl using green prana. Green prana has cleansing properties. The healer then energizes the seeds and soil with fresh electric violet prana. Electric violet prana has regeneration properties (Sui, 2009). Pranic protocol was applied during the morning by the farmer who was a trained pranic healer. Seeds of Pranic and control were sown at the same time in their respective plots. A recommended initial fertilizer dose of $\mathrm{N}: \mathrm{P}: \mathrm{K}$ @ 50:50:50 kg/ha was given as basal dose at the time of sowing (ICAR, 2019) and further there was no split application of nitrogen fertilizer. Timely required cultural practices like weeding and irrigation were given as crop maintenance.

Morphological observations like plant height $(\mathrm{cm})$, number of leaves, leaf length $(\mathrm{cm})$, leaf breadth $(\mathrm{cm})$, shoot fresh weight $(\mathrm{g})$, shoot dry weight $(\mathrm{g})$ root length $(\mathrm{cm})$, root fresh weight $(\mathrm{g})$ and root dry weight $(\mathrm{g})$ were recorded 20 days before harvest of the crop. Leaf area is calculated using leaf length and breadth and expressed as $\mathrm{dm}^{2}$.

Yield and yield related parameters like number of reproductive tillers per plant, total no of panicle/plant, panicle length $(\mathrm{cm})$, panicle fresh weight $(\mathrm{g})$, panicle dry weight (g), number of seeds/panicle, number of fingers/panicle, finger length $(\mathrm{cm}), 1000$ seed weight (g) and grain yield/plant (g) were recorded 2 weeks after the harvest of the crop (Fig. 1). Major (N, P, K, $\mathrm{Ca}, \mathrm{Mg}$ and $\mathrm{S}$ ) and micro ( $\mathrm{Fe}, \mathrm{Mn}, \mathrm{Zn}$ and $\mathrm{Cu}$ ) nutrients were analyzed in both grain and straw of ragi. Nitrogen (N) and Phosphorous (P) content in straw and grain were estimated by using a modified micro Kjeldahl method and Vanadomolybdate yellow colour method respectively (Jackson, 1973). Potassium (K) content was estimated by Flame photometric method and the Titration method was adopted for the estimation of calcium (Ca) and magnesium (Mg) (Gupta, 2000). Sulphur (S) content was estimated by adopting the turbidimetric method (Tabatabai and Bremner, 1970). Sample for estimation of micronutrients $(\mathrm{Fe}, \mathrm{Mn}, \mathrm{Zn}$ and $\mathrm{Cu}$ ) were digested initially using the di-acid mixture and were estimated using Atomic absorption spectrophotometer (AAS) (Kratochvil et al. 1990).

Morphological, yield and nutrient data were tabulated and analyzed by t-test in Microsoft Excel and the level of significance was expressed at $5 \%$ Probability $(p<.05)$ for all the parameters. The data are presented as mean and standard deviation. The data analysis for morphological and yield traits were carried out in 30 replicates, while for nutrient analysis it was in triplicates. 

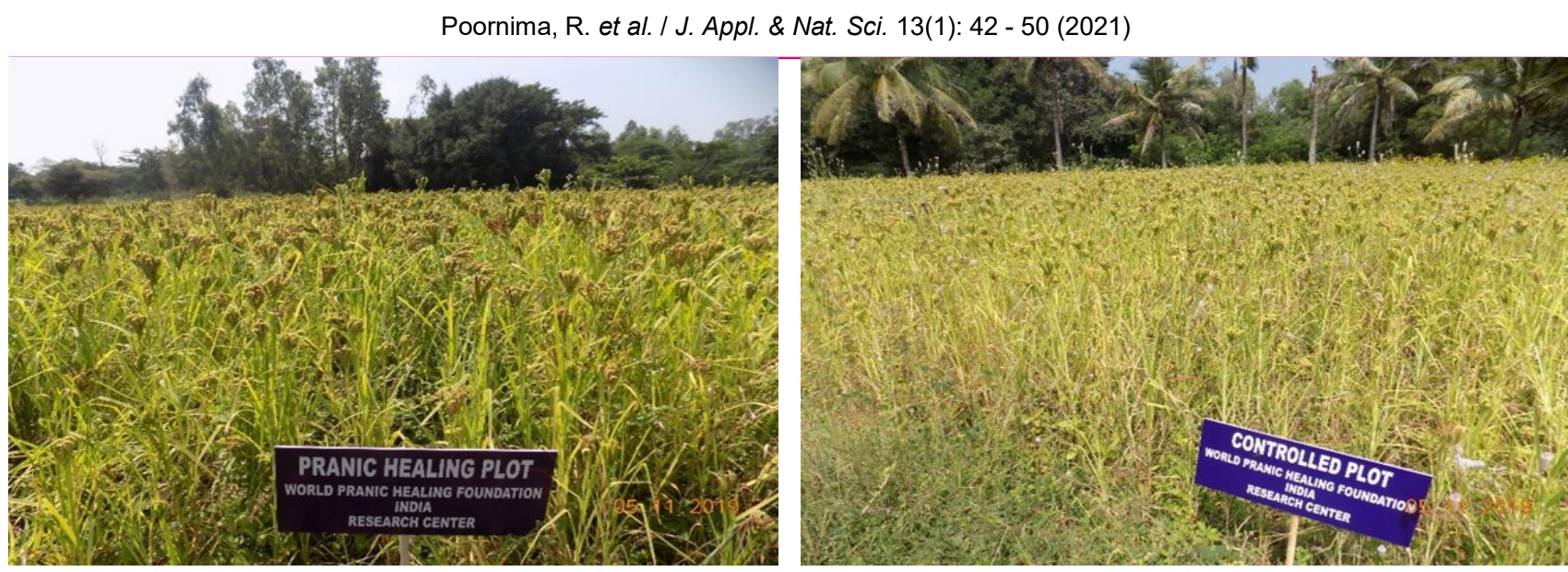

Fig. 1. Experimental view of ragi (Eleusine coracana L.) plot at harvest (Treatments - Pranic and control).

\section{RESULTS AND DISCUSSION}

Morphology of a plant determines the growth and performance of a crop and is directly related to final grain yield in most of the agriculture crops. Plant height, number of leaves and leaf area determine the photosynthetic capacity of a plant. Plant height and the number of leaves in pranic treatment were significantly $(p<.05)$ higher $(163.57 \mathrm{~cm}$ and 60.86$)$ than control $(129.4 \mathrm{~cm}$ and 10.96$)$ respectively (Table 1). Leaf area is a product of leaf length and leaf breadth and it is a site of photosynthesis and transpiration, two major physiological processes of a plant. Leaf length, leaf breadth and leaf area of pranic treated $(60.86 \mathrm{~cm}, 1.64$ $\mathrm{cm}$ and $152.43 \mathrm{dm}^{2}$ ) recorded significantly $(p<.05)$ higher than control $\left(44.6 \mathrm{~cm}, 1.08 \mathrm{~cm}\right.$ and $\left.40.9 \mathrm{dm}^{2}\right)$.

Root and shoot growth determine vegetative growth and overall biomass of the plant. Shoot weight also directly related to crop yield because it indicates the number of tillers and leaves (Wolie and Dessalegn, 2011). Shoot fresh and dry weight of pranic treated plants were 189.7 and $58.6 \mathrm{~g}$, whereas control plants recorded only 79.33 and $26.26 \mathrm{~g}$ and were statistically significant $(p<.05)$. Similarly, root length and weight are an indicator of root penetration and root diameter. Root dry weight is directly related to the root volume and root numbers. More number of roots increases water and nutrient absorption capacity and increases growth of tiller and leaves (Goron et.al., 2015). Root length of pranic treated plants $(25.6 \mathrm{~cm})$ was higher than control $(23.5 \mathrm{~cm})$, but the results were not statistically significant. Root fresh and dry weight of pranic treated plants were statistically higher $(23$ and $11.06 \mathrm{~g}$ ) than control (12.5 and 5.12g) (Table 1 and Fig. 2).

Higher plant height, leaf area, shoot and root growth are the major measures of crop absorption and photosynthetic activity. The leaf is a major chlorophyllcontaining area that captures solar energy and converts into glucose utilized by the plant for dry matter production and synthesis of grains. Leaf area or canopy is also an important principle factor in determining plants' photosynthesis (Chetti and Sirohi,1995). Enhanced leaf area is reflected in the increase of the shoot fresh and dry weight. Growth of root and shoot are inter-dependent, or they go hand in hand. Root supplies water and minerals to the upper part of the plant, whereas leaves supply glucose for the growth of root (Surendar and Jalaludhin, 2016). When a plant experiences stress, root to shoot growth and ratio varies and that modification is to avoid, resist or escape from the stress damage (Marschner.,1995). Pranic treated plants have maintained higher shoot and root growth, indicating both source and sink relationship is balanced; there is no competition for resources either from leaf or root.

In addition to more tillers, conversion of these tillers into productive tillers is also an important trait, which determines the reproductive efficiency of a crop. The large canopy is desirable for straw purpose, but a greater number of reproductive tillers are desirable from an economic yield perspective. The number of reproductive tillers per plant was 2.03 in pranic treatment, whereas it was 1.5 for control plants, which was

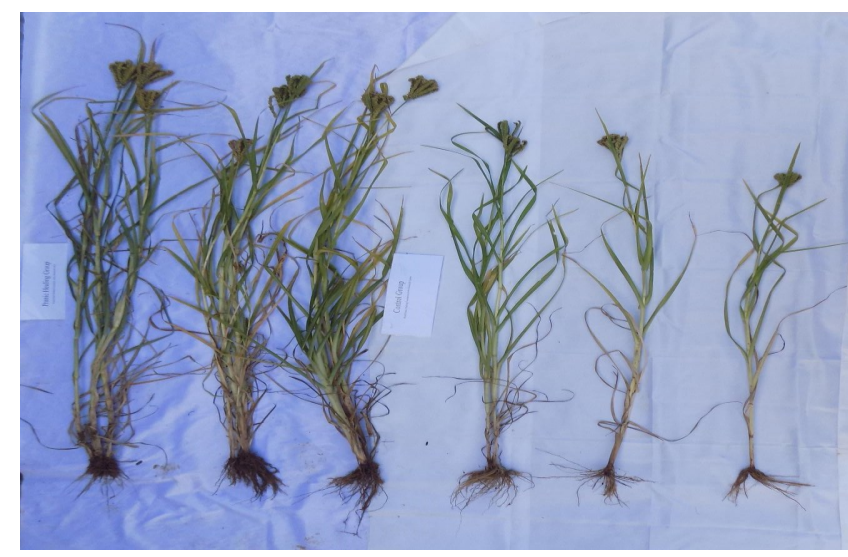

Pranic

Control

Fig. 2. Showing difference in shoot, root and panicle growth of ragi (Eleusine coracana L.) plant (Treatments - Pranic and control). 
statistically significant $(p<.05)$.

The number of panicles per plant in pranic treatment was 2.10 , whereas for control, it was 1.36 , which was statistically significant $(p<.05)$ (Table 2). Panicle fresh weight and dry weight of pranic treatment (21.67 and $10.67 \mathrm{~g})$ were significantly higher $(p<.05)$ than control (13.2 and 6.37g). Panicle length was higher in pranic treatment $(35.93 \mathrm{~cm})$ than control $(29.2 \mathrm{~cm})$. The number of grains per panicle (312.3) and the number of fingers per panicle (8.26) was found significantly higher in pranic treatment when compared to control (257.4 and 7.3) respectively. Finger length was also found significantly higher in pranic treatment $(9.6 \mathrm{~cm})$ when compared to control, which is $7.46 \mathrm{~cm}$. Seed weight (1000) and grain yield/ plant was found significantly higher in pranic treatment $(0.29$ and $18.81 \mathrm{~g})$ when compared to control $(0.25$ and $7.15 \mathrm{~g})$. Each crop and variety has its unique capacity to produce the harvest. Yield determining parameters like panicle and finger length and weight were improved by external application of pranic energy. Remobilization of photosynthates from vegetative parts to reproductive grains determines the final yield of the crop.

The protein content in straw and grain was also increased significantly by pranic treatment $(4.38 \%$ and $6.13 \%$ ) when compared to control (3.5 and $4.75 \%$ ). High-quality proteins are essential for the physical and mental wellbeing of humans, especially children (Heine et al., 1995; Tome and Bos, 2007). In general, cereals and millets contain lower levels of protein compared to legumes and animal protein. So, there is always a need to improve the protein content in the cereals and millets as it is consumed on a daily basis in larger quantities compared to other food grains (Anitha et al., 2020).

Similar to the present study, in a field experiment, the foliar application of different doses of the recommended dose of fertilizer (RDF) and humic acid combinations have been tried on ragi crop. Soil application of
$50 \%$ recommended dose of nitrogen (RDN) + foliar spay of $50 \%$ RDN and $100 \% \mathrm{P}$ and $\mathrm{K}$ through water-soluble fertilizer (20 and 40 DAT) + foliar application of humic acid $0.1 \%$ ( 20 and 40 DAT) recorded significantly higher growth parameters viz., plant height $(122.9 \mathrm{~cm})$, number of tillers plant ${ }^{-1}(9.4)$ and dry matter production $\left(12806.5 \mathrm{~kg} \mathrm{ha}^{-1}\right)$ at 90 DAT and yield attributes like number of ear plant ${ }^{-1}(6.7)$, ear head length $(10.74 \mathrm{~cm})$, number of earhead ${ }^{-1}(8.7)$, thousand seed weight $(3.0 \mathrm{gm})$, grain yield $(3776.7 \mathrm{~kg}$ $\mathrm{ha}^{-1}$ ) and straw yield (8206.8 $\left.\mathrm{kg} \mathrm{ha}^{-1}\right)$, recorded with significantly higher values (Gokul and Senthil Kumar, 2019).

In a field experiment to study the effect of various levels of fertilizers on growth and yield of Finger Millet (var GPU-28). $T_{1}$-RDF through fertilizer (60:30:00 Kg NPK/ ha), $T_{2}$-RDF through briquettes (60:30:00 Kg NPK/ha), $\mathrm{T}_{3}-75 \%$ Recommended dose of fertilizers through briquettes (45:22.5:00 Kg NPK/ha), $\mathrm{T}_{4}-50 \%$ RDF through briquettes $(30: 15: 00 \mathrm{Kg} \mathrm{NPK/ha),} \mathrm{farmers} \mathrm{practice}$ (application of $125 \mathrm{~kg} \mathrm{Urea/ha)} \mathrm{and} \mathrm{T}_{6}$ Absolute control. Treatment $\mathrm{T}_{2}$ recorded significantly higher grain yield (25.20 q/ha) and straw yield (32.72 q/ha). Application of fertilizer with briquettes was optimum for maximum yield (Patil et al., 2015).

Similarly, in the present study fertilizer (N: P: K @ 50:50:50 kg/ha) was applied only as basal dose during sowing, but not given any fertilizer during growth stages. With minimum fertilizer application, pranic treatment has given growth and yield on par with the expected yield of the variety whereas in control, there was no increase in growth and yield. Thus, pranic energy application can compensate with the reduced application of fertilizer and give a higher yield. PA can reduce the application of chemical fertilizer, and farmers could benefit by reducing the cost of cultivation. Environmental sustainability also can be achieved.

Nutrients analysis was done for major and minor nutri-

Table 1. Effect of pranic treatment on morphological growth of ragi (Eleusine coracana L.) plant.

\begin{tabular}{lccccccc}
\hline \multirow{2}{*}{ Traits } & \multicolumn{2}{c}{ Pranic } & \multicolumn{2}{c}{ Control } & \multicolumn{2}{c}{ t-test statistics } & Increase over \\
\cline { 2 - 6 } control (\%)
\end{tabular}

*Significant at $p<.05$ 
ents content in straw and grain of ragi crop (Table 3 ). Major nutrients $(\mathrm{mg} / 100 \mathrm{~g})$ like nitrogen $(700)$, phosphorous (330), potassium (880), calcium (1610) and magnesium $(570)$ were significantly higher $(p<.05)$ in pranic treatment as compared to control $(560,250,690,1450$ and 360) except for Sulphur. Minor nutrients $((\mathrm{mg} / 100 \mathrm{~g})$ like manganese (24.82) and zinc (19.85) showed significantly higher levels in pranic treatment than control (19.85 and 1.43). Whereas iron showed significant variation among treatment, but the values are higher in control (67.04) when compared to pranic treatment (51.6). Copper content was non significantly varying among pranic (0.94) and control (1.02) treatments. External factors besides varietal variation influences on accumulation of mineral content in grains. Dense root system with many root hairs is better to absorb more nutrients because of its higher root surface area. Root surface to volume ratio determines water and nutrient uptake (Gahoonia et al. 2007, Morgan and Connolly, 2013). The increase in nutrient content in pranic treatment of ragi straw might be because of an increase in root volume and root surface area evidence by higher root dry weight. Agricultural crop residues especially straw and stovers, form the major cattle feed in many countries, especially in India. Among them, rice and ragi are the major nutritive cattle feed in southern India (Gowda and Prasad, 2004; Suresh and Chandrakanth,2015). So, the increase in protein and nutritional content of ragi straw is a beneficial effect obtained by pranic treatment.

Nitrogen and Zinc content in grain is significantly varying among pranic and control treatments. Like in straw, the variation in nutrient content was not significantly different for all the nutrients except Sulphur. Major nutrient nitrogen $(\mathrm{N}, \mathrm{mg} / 100 \mathrm{~g})$ and minor nutrients zinc $(\mathrm{Zn}$, $\mathrm{mg} / 100 \mathrm{~g}$ ) content was significantly improved in pranic treatment (980 and $1.96 \mathrm{mg} / 100 \mathrm{~g}$ ) when compared to control $(760 \mathrm{mg} / 100 \mathrm{~g})$ and 1.63) (Table 4). Reviewing of nutrient content $(\mathrm{mg} / 100 \mathrm{~g})$ in ragi varieties, other millets and cereals were done and found protein content $(7.3 \mathrm{~g})$, phosphorous $(283 \mathrm{mg} / 100 \mathrm{~g})$, potassium $(408 \mathrm{mg} / 100 \mathrm{~g})$, calcium $(344 \mathrm{mg} / 100 \mathrm{~g}))$, magnesium $(137 \mathrm{mg} / 100 \mathrm{~g})$, Sulphur $(160 \mathrm{mg} / 100 \mathrm{~g})$, manganese $(5.49 \mathrm{mg} / 100 \mathrm{~g})$, iron $(3.9 \mathrm{mg} / 100 \mathrm{~g})$, zinc $(2.3 \mathrm{mg} / 100$ $\mathrm{g})$ and copper $(0.47 \mathrm{mg} / 100 \mathrm{~g})$ in ragi grain (Geervani and Eggum,1989, Shobana et al., 2013).

Accumulation of nutrients in the edible grain is the major priority for any crop improvement. There are different mechanisms involved for nutrient uptake, translocation and accumulation (Marschner,1995). Similarly, in the present study, the nutrient uptake and translocation were high, which is evident by the nutrient content in the straw but at accumulation point, the same is not reflected except for $\mathrm{N}$ and $\mathrm{Zn}$. So, there is an improvement in the nutrient content of straw by pranic treatment and useful for cattle feed, but when grain nutrition is considered, only $\mathrm{N}$ and $\mathrm{Zn}$ content are improved. The probable reason might be that there is a gap between the remobilization of nutrient from the vegetative part to the reproductive part as seen for most of the nutrient. It is a challenging mechanism to be addressed further. The transport distance and redistribution might have played a role in the varied type of accumulation of nutrients (Stieger et al., 1994; Marschner,1995; Park et al., 2008). Nitrogen is a vital key nutrient required in major quantity by the plants for synthesis of protein, amino acid, DNA and RNA. N is the major component of chlorophyll where photosynthesis takes place. So, the increase in $\mathrm{N}$ content in both straw and grain of ragi is very much advantageous for animal and human consumption (Taiz and Zeiger., 2010). $\mathrm{Zn}$ is also an important micronutrient after iron from a human health point is concerned and its fourth major micronutrient deficiency found in the world (Cakmak, 2008). Zinc content in cereals is less as compared to pulses and oilseeds. Hence improvement in

Table 2. Effect of pranic treatment on yield traits of ragi (Eleusine coracana L.) plant.

\begin{tabular}{|c|c|c|c|c|c|c|c|}
\hline \multirow{2}{*}{ Traits } & \multicolumn{2}{|c|}{ Pranic } & \multicolumn{2}{|c|}{ Control } & \multicolumn{2}{|c|}{ t-test statistics } & \multirow{2}{*}{$\begin{array}{c}\text { Increase over } \\
\text { control (\%) }\end{array}$} \\
\hline & Mean & SD & Mean & SD & t-value & Sig. & \\
\hline No. of productive tillers & 2.03 & 1.06 & 1.50 & 0.73 & $2.25^{*}$ & 0.027 & 35 \\
\hline No. of panicle/plant & 2.10 & 1.32 & 1.36 & 0.67 & $2.71^{*}$ & 0.008 & 54 \\
\hline Panicle fresh weight $(\mathrm{g})$ & 21.67 & 6.76 & 13.20 & 6.31 & $5.02^{*}$ & 0.000 & 64 \\
\hline Panicle dry weight (g) & 10.67 & 3.78 & 6.37 & 3.38 & $4.63^{*}$ & 0.000 & 67 \\
\hline Panicle length $(\mathrm{cm})$ & 9.60 & 8.93 & 7.46 & 5.22 & $6.93^{*}$ & 0.000 & 28 \\
\hline No of seeds/panicle & 312.3 & 74.37 & 257.4 & 101.9 & $2.38^{*}$ & 0.020 & 21 \\
\hline No of fingers/panicle & 8.26 & 1.43 & 7.30 & 1.08 & $2.93^{*}$ & 0.004 & 13 \\
\hline 1000 seed weight $(\mathrm{g})$ & 2.9 & 0.06 & 2.5 & 0.06 & $2.42^{*}$ & 0.018 & 13 \\
\hline Grain yield/plant (g) & 18.81 & 14.29 & 13.02 & 3.31 & $2.15^{*}$ & 0.035 & 163 \\
\hline Straw protein content (\%) & 4.38 & 0.13 & 3.5 & 0.13 & $-8.57^{*}$ & 0.001 & 25 \\
\hline Seed protein content (\%) & 6.13 & 0.19 & 4.75 & 0.13 & $-10.57^{*}$ & 0.000 & 29 \\
\hline
\end{tabular}

${ }^{*}$ Significant at $p<.05$ 
Poornima, R. et al. / J. Appl. \& Nat. Sci. 13(1): 42 - 50 (2021)

Table 3. Influence of pranic treatment on the nutrient content of ragi (Eleusine coracana L.) straw.

\begin{tabular}{|c|c|c|c|c|c|c|}
\hline \multirow{2}{*}{$\begin{array}{l}\text { Straw nutrient content } \\
(\mathrm{mg} / 100 \mathrm{~g})\end{array}$} & \multicolumn{2}{|c|}{ Pranic } & \multicolumn{2}{|c|}{ Control } & \multicolumn{2}{|c|}{ t-test statistics } \\
\hline & Mean & SD & Mean & SD & t-value & Sig \\
\hline Nitrogen & 700 & 20 & 560 & 20 & $-8.57^{*}$ & 0.000 \\
\hline Phosphorus & 330 & 20 & 250 & 10 & $-6.19^{*}$ & 0.003 \\
\hline Potassium & 880 & 60 & 690 & 20 & $-11.63^{*}$ & 0.000 \\
\hline Calcium & 1610 & 40 & 1450 & 60 & $-3.84^{*}$ & 0.010 \\
\hline Magnesium & 570 & 30 & 360 & 20 & $-11.49^{*}$ & 0.000 \\
\hline Sulphur & 110 & 20 & 110 & 20 & 0.00 & 1.000 \\
\hline Manganese & 24.82 & 0.11 & 19.85 & 0.14 & $-47.49^{*}$ & 0.000 \\
\hline Iron & 51.61 & 0.09 & 67.04 & 0.18 & $131.71^{*}$ & 0.000 \\
\hline Zinc & 2.37 & 0.08 & 1.43 & 0.04 & $-20.33^{*}$ & 0.000 \\
\hline Copper & 0.94 & 0.05 & 1.02 & 0.04 & 2.164 & 0.090 \\
\hline
\end{tabular}

${ }^{*}$ Significant at $p<.05$

Table 4. Influence of pranic treatment on the nutrient content of ragi (Eleusine coracana L.) grain.

\begin{tabular}{lcccccc}
\hline \multirow{2}{*}{$\begin{array}{l}\text { Grain nutrient content } \\
(\mathbf{m g} / \mathbf{1 0 0} \mathbf{g})\end{array}$} & \multicolumn{2}{c}{ Pranic } & \multicolumn{2}{c}{ Control } & \multicolumn{2}{c}{ t-test statistics } \\
\cline { 2 - 7 } & Mean & SD & Mean & SD & t-value & Sig \\
\hline Nitrogen & 980 & 30 & 760 & 20 & $-10.56^{*}$ & 0.000 \\
Phosphorus & 320 & 20 & 360 & 20 & 2.44 & 0.070 \\
Potassium & 440 & 20 & 470 & 20 & 1.83 & 0.140 \\
Calcium & 260 & 10 & 380 & 10 & 1.04 & 0.350 \\
Magnesium & 270 & 20 & 270 & 20 & 0.00 & 2.770 \\
Sulphur & 70 & 10 & 80 & 10 & 1.22 & 2.770 \\
Manganese & 16.52 & 0.10 & 16.44 & 0.11 & -0.93 & 0.401 \\
Iron & 4.47 & 0.15 & 4.72 & 0.08 & 1.99 & 0.140 \\
Zinc & 1.96 & 0.04 & 1.63 & 0.06 & $-7.96^{*}$ & 0.001 \\
Copper & 0.76 & 0.01 & 0.85 & 0.01 & 13.1 & 2.770 \\
\hline
\end{tabular}

*Significant at $p<.05$

$\mathrm{Zn}$ content by $\mathrm{PA}$ in ragi grain is a promising result. Genetic factors affecting $\mathrm{Zn}$ and protein concentration in grain are positively correlated (Morgounov et al., 2007) and the same effect is evident by giving the pranic treatment. Increase in protein and zinc content of grain helps to combat malnutrition in major ragi consuming countries like India, Nepal, Niger, Mali, Nigeria and Burkina in their daily diet.

Studies have concluded that plants have a signalling system similar to primitive animals and have receptors to receive the signal and conductors to electrically code and process the signal and terminal motor organs to respond to the stimuli. The physiological mechanism of the plants is identical to that of the animal. He established the nervous impulse and its transmission in plants, responsible for the control of many physiological functions including growth, the ascent of the sap, respiration, photosynthesis, motor activity and response to the environment - light, heat, trauma, shock, and drugs and toxins (Bose., 1902,1906,1926 and Tandon, 2019). Plants respond to the external stimulus like light, temperature, sound and magnetic waves. Similarly, pranic energy projected on the plant might be received by the plant surface by receptors as a signal and the same might have been transmitted inside the plant and further physiological changes have taken place.

It is revealed that plants sense and respond to their environment by producing electrical signals that represent changes in underlying physiological processes (Volkov and Ranatunga, 2006). In another study on tomato and cucumber, an attempt was made to explore the possibility of classifying three external stimulisodium chloride $(\mathrm{NaCl})$, Sulphuric acid $\left(\mathrm{H}_{2} \mathrm{SO}_{4}\right)$ and ozone $\left(\mathrm{O}_{3}\right)$, from the electrical signal response of plants as the first step towards developing a biosensor. Development of multiple-stimuli sensing biological sensor devices helps in timely monitoring environmental stimuli and holistically prepare the plant to respond as and when required. (Chatterjee et al., 2015).

Music has a profound effect on human beings. Similarly, even though plants are devoid of the nervous system, but few studies have shown that plants can understand music or respond to music. However, a few studies suggest that music may have a distinct effect on 
plants like plant protection and protein production in wheat, spinach, horse gram, soya and paddy (Reddy and Ragavan, 2013). A study by Sharma ( 2015), showed that in addition to yield music also significantly influenced on synthesis of metabolites like chlorophyll and starch. In another study, chickpea (Cicer arietinum) and marigold (Tagetes sp.) were exposed to light Indian music, noise and meditation. Results showed that music promoted the growth and development of the plants, including germination, whereas noise hindered it. Music might facilitate better physiological processes like absorption of nutrients, photosynthesis, protein synthesis, etc. for the plant and this is observable in terms of increased height, higher number of leaves and overall, more developed and healthier plants (Chowdhury and Gupta, 2015).

In another similar study, yogic farming was performed through Brahma Kumari's Raja Yoga meditation. On wheat seedlings, metaphysical energy was imposed and found a significant increase in shoot length, root length and seedling vigour when compared to control. Yield parameters like ear head length, ear head number, biomass, grain yield, 100 grain weight and grain protein were higher in yogic treatments in the combination of organic and inorganic fertilizer treatments. The positive metaphysical energy might have influenced the water present inside the seed as well as the water used for germination, and this positive, powerful thought vibration energy might have improved the primary metabolic functions (Pandey et al., 2015). In the present study, PA application has improved yield and nutrient content in the ragi crop and the exact mechanism needs to be investigated. A further detailed study is needed to find out how the pranic healing projected on plants is influencing on plant behaviour in terms of growth, yield and quality improvement.

\section{Conclusion}

Pranic Agriculture (PA) practice in finger millet (E. coracana) has shown a significant increase $(p<.05)$ in traits like plant height, number of leaves, leaf area, shoot fresh weight and dry weight, root fresh and dry weight. Similarly, yield traits like number panicle, panicle length, fresh and dry weight, number of seeds and fingers, grain yield per plant have been significantly $(p<.05)$ improved by PA practice. Further, the increase in protein and major and minor nutrient content in ragi grain and straw are beneficial for human and cattle consumption. Thus, PA can also reduce the application of fertilizer and maintain soil and environment sustainability. So, by adopting PA, the yield and nutrition of the crops can be improved and further studies are needed to find out the reasons for actual mechanisms involved in the improvement of the crop.

\section{ACKNOWLEDGEMENTS}

The authors would like to thank Master Choa Kok Sui, founder of Pranic Healing and Pranic Agriculture technique, Trustees of World Pranic Healing Foundation, India for funding, encouragement and support, Ashok S. for lending his agriculture land to do this study and all those who contributed directly and indirectly to this study.

\section{Conflict of Interest}

The authors declare that they have no conflict of interest.

\section{REFERENCES}

1. Anitha S., Govindaraj M. \& Kane $\square$ Potaka, J. (2020). Balanced amino acid and higher micronutrients in millets complements legumes for improved human dietary nutrition. Cereal Chemistry, 97(1), 74-84. https:// doi.org/10.1002/cche.10227 für analytische Chemie, 310 (1-2), 13-15.

2. Bose, J.C. (1906). Plant Response as a means of Physiological Investigation, London, New York \& Bombay: Longmans, Green \& Co, https://doi.org/10.5962/bhl.title.12980

3. Bose, J. C. (1902). Response in the Living and Non-living, London, New York \& Bombay: Longmans, Green \& Co, https://archive.org/details/responseinliving1902bose

4. Bose, J.C. (1926). The nervous mechanisms of plants London: Longmans, Green and Co, http:// www.drmichaellevin.org/Nervous $\% 20$ mechanism\%20of\% 20plants.pdf

5. Chatterjee, S. K., Das, S., Maharatna, K., Masi, E., Santopolo, L., Mancuso, S \& Vitaletti, A. (2015). Exploring strategies for classification of external stimuli using statistical features of the plant electrical response. Journal of the Royal Society Interface, 12,20141225. https:// doi.org/10.1098/rsif.2014.1225

6. Cakmak, I. (2008). Enrichment of cereal grains with zinc: agronomic or genetic biofortification? Plant and Soil, 302 (1-2): 1-17. https://doi.org/10.1007/s11104-007-9466-3

7. Chandra, D., Chandra, S. \& Sharma, A. K. (2016). Review of Finger millet (Eleusine coracana (L.) Gaertn): a power house of health benefiting nutrients. Food Science and Human Wellness, 5(3), 149-155. https://doi.org/10.1016/ j.fshw.2016.05.004

8. Chandrasekharaiah, M., Sampath, K. T \& Praveen, U. S. (2004). Effect of strategic supplementation of finger millet straw on milk yield in crossbred cows: On farm trial. Indian Journal of Dairy Science 57(3): 192-197.

9. Chetti, M. B \& Sirohi, G. S. (1995). Effects of Water Stress on Leaf Characteristics and its Recovery in Mungbean Cultivars. Journal-Maharashtra Agricultural Universities 20, 85-87

10. Chowdhury, A. R \& Gupta, A. (2015). Effect of music on plants-an overview. International Journal of Integrative Sciences, Innovation and Technology 4(6): 30-34.

11. Gahoonia, T. S., Ali, R., Malhotra, R. S., Jahoor, A \& Matiur, R. (2007). Variation in root morphological and physiological traits and nutrient uptake of chickpea genotypes. 
Journal of Plant Nutrition, 30, 829-841. https:// doi.org/10.1080/15226510701373213

12. Geervani, P \& Eggum, O. (1989). Nutrient composition and protein composition of minor millets. Plant Foods for Human Nutrition, 39: 201-208. https://doi.org/10.1007/ BF01091900

13. Gokul, G \& Senthil Kumar, N. (2019). Effect of Foliar Feeding Technique on Growth and Yield of Ragi. Plant Archives, 19(2): 2889-2892.

14. Goron, T. L., Bhosekar, V. K., Shearer, C. R., Watts, S \& Raizada, M. N. (2015). Whole plant acclimation responses by finger millet to low nitrogen stress. Frontiers in Plant Science, 6, 652. doi: 10.3389/fpls.2015.00652

15. Gowda, N. K. S \& Prasad, C. S. (2004). Macro and Micronutrient Utilization and Milk Production in Crossbred Dairy Cows Fed Finger Millet (Eleucine coracana) and Rice (Oryza sativa) Straw as Dry Roughage Source, AsianAustralian Journal of Animal Science, 18(1), 48-53. https://doi.org/10.5713/ajas.2005.48.

16. Gupta, P. K. (2000). Methods in environmental analysis: Water, Soil and Air. Agrobois, 4(3), 5-76.

17. Heine, W., Radke, M \& Wutzke, K. D. (1995). The significance of tryptophan in human nutrition. Amino Acids. 9, 191-205. doi: 10.1007/BF00805951

18. ICAR (2019). Indian Council of Agricultural Research http://agrigoaexpert.res.in/icar/category/agriculture/ fieldcrops/millet/Ragi.php. Accessed on 13.01.2021.

19. Jackson, M. L. (1973). Soil Chemical Analysis, Prentice Hall of India Private Limited, New Delhi. pp. 183-192.

20. Jois, S. N., Prasad, N. K and Shalini, N.S. (2019). Enhancement of shelf life of brinjal during storage using pranic agriculture protocol. Ecology, Environment and Conservation,25(3),1251-1254.

21. Jois, S. N., Prasad, N. K \& D'Souza, L. (2017). Morphology of Cucumber plants as influenced by Pranic Agriculture. Asian Journal of Agricultural Research, 11, 33-35. DOI: 10.3923/ajar.2017.33.35

22. Jois, S. N., Roohie, K., D'Souza, L., Suma, F \& Devaki, C. S. (2016). Physico-chemical qualities of tomato fruits as influenced by pranic treatment - an ancient technique for enhanced crop development. Indian Journal of Science and Technology, 9(46): 1-6. http:// DOI:10.17485/ ijst/2016/v9i46/99733

23. Kennedy, M. M., Grootboom, A \& Shewry, P. R. (2006). Harnessing sorghum and millet biotechnology for food and health. Journal of Cereal Science, 44(3): 224-235. https://doi.org/10.1016/j.jcs.2006.08.001

24. Kirlian, S. D. (1949). Method for receiving photographic pictures of different types of objects. Patent, N106401 USSR.1949.

25. Kratochvil, B \& Mamba, S. (1990). Microwave acid dissolution of soil samples for elemental analysis. Can. $J$. Chem., 68, 360-362.

26. Marschner, H. (1995). Mineral nutrition of higher plants 2nd edition. Academic, Great Britain.

27. Morgan, J. B. \& Connolly, E. L. (2013) Plant-Soil Interactions: Nutrient Uptake. Nature Education Knowledge 4(8), 2

28. Morgounov, A., Gómez-Becerra, H. F., Abugalieva, A., Dzhunusova, M., Yessimbekova, M., Muminjanov, H., Hafiz, M., Yu, Z., Levent, O \& Cakmak, I. (2007). Iron and zinc grain density in common wheat grown in Central
Asia. Euphytica, 155(1-2), 193-203. DOI 10.1007/s10681006-9321-2

29. Pandey, S. T., Verma, O., Kewalanand \& Pandey, D. S. (2015). Yogic farming through Brahma Kumaris Raja Yoga Meditation: An Ancient Technique for enhancing crop performance. Asian Agri-History, 19(2): 105-122, https:// eco.brahmakumaris.org/wp-content/uploads/2020/03/ Asian_Agri-History_2015_sm-2.pdf

30. Park, J., Kim, Y. Y., Martinoia, E \& Lee, Y. (2008). Longdistance transporters of inorganic nutrients in plants. Journal of Plant Biology, 51(4), 240-247.

31. Patil, S. V., Bhosale, A. S \& Khambal, P. D. (2015). Effect of various levels of fertilizers on growth and yield of finger millet. IOSR Journal of Agriculture and Veterinary Science 8(6), 49-52. DOI: 10.9790/2380-08614952

32. Poornima, R., Prasad, N., Yathindra, H. A \& Jois, S.N. (2020). Influence of Pranic Agriculture on morphological traits, chlorophyll content and genetic polymorphism of Ridge gourd (Luffa acutangula L. Roxb.) assessed by RAPD marker analysis. AGRIVITA, Journal of Agricultural Science, 42(3). DOI: http://doi.org/10.17503/agrivita.v4 2i3.2715

33. Prasad, N. K \& Jois, S. N. (2019). Pranic agriculture improves drumstick (Moringa olifera L.) germination and seedling growth. Ecology, Environment and Conservation 25(4), 1752-1755

34. Prasad, N. K \& Jois, S. N. (2020). Enhancement of Papaya (Carica papaya) Seedling Growth by Pranic Agriculture. AGRIVITA, Journal of Agricultural Science. 42(1): 191-196. DOI: http://doi.org/10.17503/agrivita.v42i1.2410.

35. Reddy, K. G \& Ragavan, R. (2013). Classical ragas: A new protein supplement in plants. Indian Journal of Life Sciences, 3(1), 97

36. Scalbert, A., Manach, C., Morand, C., Remesy, C \& Jimenez, L. (2005). Dietary polyphenols and the prevention of diseases, Critical Review in Food Science and Nutrition, 45 (4), 287-306. https://doi.org/10.1080/104 0869059096

37. Sharma, D., Gupta, U., Fernandes, A. J., Mankad, A \& Solanki, H. A. (2015). The effect of music on physicochemical parameters of selected plants. Int. J. of Plant, Animal and Environmental Sciences, 5(1), 282-287.

38. Shobana, S., Krishnaswamy, K., Sudha, V., Malleshi, N. G., Anjana, R. M., Palaniappan, L \& Mohan, V. (2013). Finger Millet (Ragi, Eleusine coracana L.). A review of its nutritional properties, processing and plausible health benefits. Advances in Food and Nutrition Research, 69, 1-39. Doi:10.1016/b978-0-12-410540-9.00001-6.

39. Stieger, P. A \& Feller, U. (1994). Nutrient accumulation and translocation in maturing wheat plants grown on waterlogged soil. Plant and Soil, 160 (1), 87-95. https:// doi.org/10.1007/BF00150349

40. Sui, C. K. (2009). Advanced Pranic Healing: A Practical Manual for Color Pranic Healing. World Pranic Healing Foundation, India. Bangalore ISBN: 971-91106-4-3

41. Sui, C. K. (2015). The ancient science and art of pranic healing (3rd ed.). Manila: $\mathrm{PH}$ : Institute for Inner Studies Publishing Foundation, Inc.

42. Surendar, K. K \& Jalaludhin, S. M. (2016). Study of morpho-physiological and root characters of ragi (Eleusine coracana) entries under rainfed conditions. Electronic Journal of Plant Breeding, 7(4), 1110-1113. 
DOI : 10.5958/0975-928X.2016.00153.8

43. Suresh, K., \& Chandrakanth, M. G. (2015). Total factor productivity and returns to investment in Ragi (finger millet) crop research in Karnataka state, India. Indian Journal of Economics and Development 3, (3), 199-205.

44. Taiz, L \& Zeiger, E. (2010). Plant physiology, 5th edn Sinauer Associates Inc., Massachusetts, $781 \mathrm{pp}$.

45. Tandon, P. N. (2019). Jagadish Chandra Bose \& plant neurobiology, Indian Journal of Medical Research. 149, 593-599. DOI: 10.4103/ijmr.IJMR_392_19

46. Tome, D \& Bos, C. (2007). Lysine requirement through the human life cycle. Journal of Nutrition. 137:1642S1645S. https://doi.org/10.1093/jn/137.6.1642S

47. Tabatabai, M. A \& Bremner, J. M. (1970). A simple turbidimetric method of determining total sulfur in plant materials
1. Agronomy Journal, 62(6), 805-806.

48. Upadhyaya, H. D., Gowda, C. L., Pundir, R. P. S., Reddy, V. G \& Singh, S. (2006). Development of core subset of finger millet germplasm using geographical origin and data on 14 quantitative traits. Genetic Resources \& Crop Evolution 53, 679-685. doi: 10.1007/s10722-004-3228-3.

49. Volkov, A. G \& Ranatunga, D. R. A. (2006). Plants as environmental biosensors. Plant Signaling and Behavior, 1(3), 105-115.

50. Wolie, A \& Dessalegn, T. (2011). Correlation and path coefficient analyses of some yield related traits in finger millet (Eleusine coracana (L.) Gaertn.) germplasms in northwest Ethiopia. African Journal of Agricultural Research, 6,5099-5105. https://doi.org/10.5897/AJAR11.616 